\title{
ANALYSIS OF MICROSCOPIC WEAR ON STRAIGHT GEAR WITH ROTATION VARIATION
}

\author{
Febri Putra Perdana, Darto*, I Made Sunada \\ Department of Mechanical Engineering, University of Merdeka Malang \\ *Email corresponding author: darto@unmer.ac.id
}

\begin{abstract}
Wear is an important factor in reducing the function of engine performance including limiting the service life and performance of various engine components that rub against each other directly, this results in increased maintenance costs. In this study aims to determine the rate of straight gear wear with SCM 440 material from the influence of load and shaft rotation. Experimental research methods with variables of $200 \mathrm{rpm}, 500 \mathrm{rpm}$ and $1000 \mathrm{rpm}$ and load respectively $0,5,10 \mathrm{~kg}$, from the test results obtained the highest value of power at $1000 \mathrm{rpm}$ and $0 \mathrm{~kg}$ load, while for the lowest wear value obtained at $200 \mathrm{rpm}$ and a load of $5 \mathrm{~kg}$, this is due to the misalignment factor in the drive shaft and being driven, this can be seen from the average wear position located at the end of the gear that is in direct contact between the gear and the gear is moved, so that in rotation high and without loading the shaft rotation is not balanced, but at high rotation and with a certain load imbalance rotation due to misalignment can be suppressed and produce a low wear value.
\end{abstract}

Keywords: Gears, wear, rotation, load

\section{INTRODUCTION}

\section{Background}

Wear is an important factor in reducing machining functions including limiting the service life and performance of various engine components, this results in an increase in maintenance costs. "The $70 \%$ reduction in the function of an engine component is caused by damage to the metal surface which includes wear (55\%) and corrosion (15\%). The dominant wear mechanisms are adhesive wear (25\%), and abrasive $(20 \%)$, while the rest is caused by other wear mechanisms (Rabinowicz, 1995) ".

The gear is one of the engine elements designed to transfer power and motion from one mechanical part to another. The gear wheel is one of the most widely used engine elements in power transmission systems, like all mechanical components in general. , gears also experience wear due to mechanical contact. In general, the contact area between the gears has a rectangular shape and can be classified under the line contact problem. The contact that occurs in the gear is in the form of informal contact and is included in elastic deformation. Nonformal contact and elastic deformation are categorized as Elasto Hydrodynamic Lubrication (EHL) line contacts. In fact, the surface of the gear is not smooth. The actual contact that occurs is between Asperiti on the surface of the gear. Contact pressure and contact load have an important 
role in the coefficient of friction and power loss (Akbarzadeh and Khonsari, 2011).

Because the gears work continuously, the gears will continue to rotate, so the impact is that the gears will wear out over time. The problem with damage to engine components that always operate and rub against each other is that wear can occur. Wear is the decomposition of surface thickness due to friction that occurs in loading and movement. Wear and tear is generally analogous to the loss of material as a result of the mechanical interaction of two surfaces rubbing against each other and being loaded.

Machines and equipment and their component components must receive operational loads and environmental loads in performing their functions. Load can be in the form of force, moment, deflection, temperature, pressure and others. Loading analysis in the design of machines or machine components is very important, because if the load is known, the dimensions, strengths, materials, and other design variables can be determined.

Based on this background, we need a "wear analysis microscopic straight gears with certain rotation variations". This research aimed to analyze straight gear wear with variations in turns and analyze microscopic straight untreatment gear wear rate.

\section{METHODOLOGY}

\section{Research Flowchart}

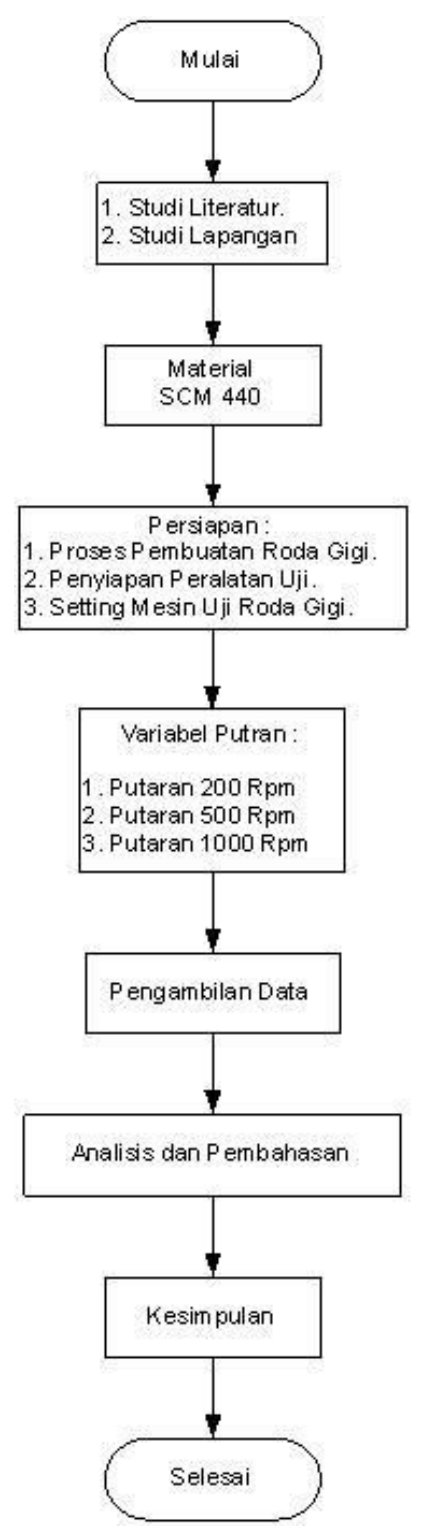

Figure 1. Research flowchart

\section{Materials}

In this research, the material used in straight gears with 18 teeth is the 
untreatment material for the SCM 440 material with the main tensile strength of 850-100Mpa. SCM440 reacted well

in heat treated and easy to process under heat treated conditions. This material provides many desirable properties such as good strength and wear resistance, excellent toughness, good ductility and resistance to high temperature stress.

Characteristic of SCM 440 :

a. High strength and toughness.

b. Good hardenable cooling property.

c. Good machining performance under high temperature and good appearance after machining.

d. Good performance in weldability.

e. Better tensile strength and elongation percentage than chromium steel.

f. Combine with $\mathrm{Cr}$ and Mo, High hardness.

Application of SCM 440 :
a. Gear
d. Winch
b. Shaft
e. Nut
c. Screw
f. Bobbin

Specification of spur gear:
a. Spur gear.
b. Tooth M3 x 18.
c. Diameter 60 × $18 \mathrm{~mm}$.

d. Naf diameter $3610 \mathrm{~mm}$.

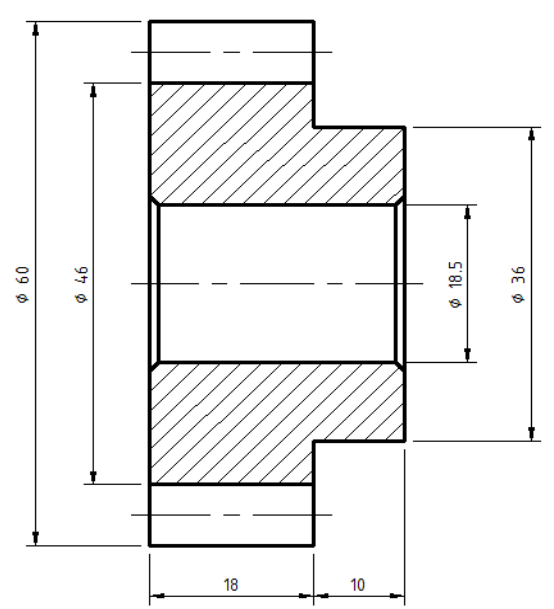

Figure 2. Gear Fixture Cross Section Details

\section{Test Gear Specimen}

In this study, the specimens to be tested were gears number 1-9.

\section{Dependent variables:}

- Load: $0 \mathrm{~kg}$.

- $\quad$ Load : $5 \mathrm{~kg}$.

- Load : $10 \mathrm{~kg}$.

\section{Dependent variables}

- Rotation: $200 \mathrm{rpm}$.

- Rotation: 500 rpm.

- Rotation: 1000 rpm.

Table 1. Test Gear Specimen.

\begin{tabular}{|c|c|c|c|}
\hline \multirow{2}{*}{$\begin{array}{c}\text { TREATMIENT } \\
\text { SPECIMENT }\end{array}$} & NO. RODA & BEBAN (P) & PUTARAN (n) \\
\cline { 3 - 4 } & GIGI & $(\mathrm{kg})$ & $(\mathrm{rpm})$ \\
\hline \multirow{5}{*}{ UN TREATMENT } & 1 & 0 & 200 \\
\cline { 2 - 4 } & 2 & 0 & 500 \\
\cline { 2 - 4 } & 3 & 0 & 1000 \\
\cline { 2 - 4 } & 4 & 5 & 200 \\
\cline { 2 - 4 } & 5 & 5 & 500 \\
\cline { 2 - 4 } & 6 & 5 & 1000 \\
\cline { 2 - 4 } & 7 & 10 & 200 \\
\cline { 2 - 4 } & 8 & 10 & 500 \\
\cline { 2 - 4 } & 9 & 10 & 1000 \\
\hline
\end{tabular}




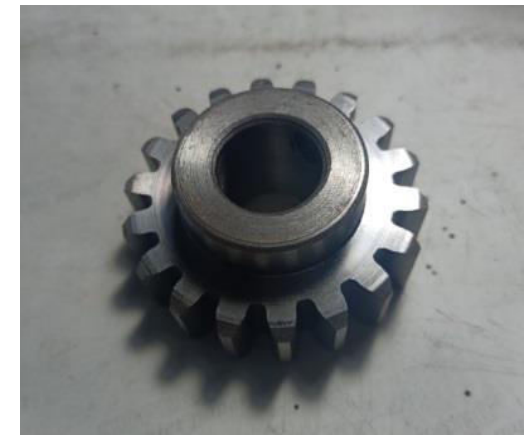

Figure 3. Straight Gear Specimen

\section{Data Collection Steps}

1. Test the gear with certain rotation variations and load variations on the gear test machine within 2 hours 30 minutes. Every 30 minutes, the engine is turned off and off the gear for photo-wear processes. The gears are mounted on the vise so that they do not move and stay in a precise position without changing places. For photo taking, 18 teeth were taken. by using an endoscope camera that is directly connected to the laptop

2. Inserting the gear image that is already in the photo into Auto Cad. Then sketch and calculate the area of gear wear.

3. Input data into Ms. Excel
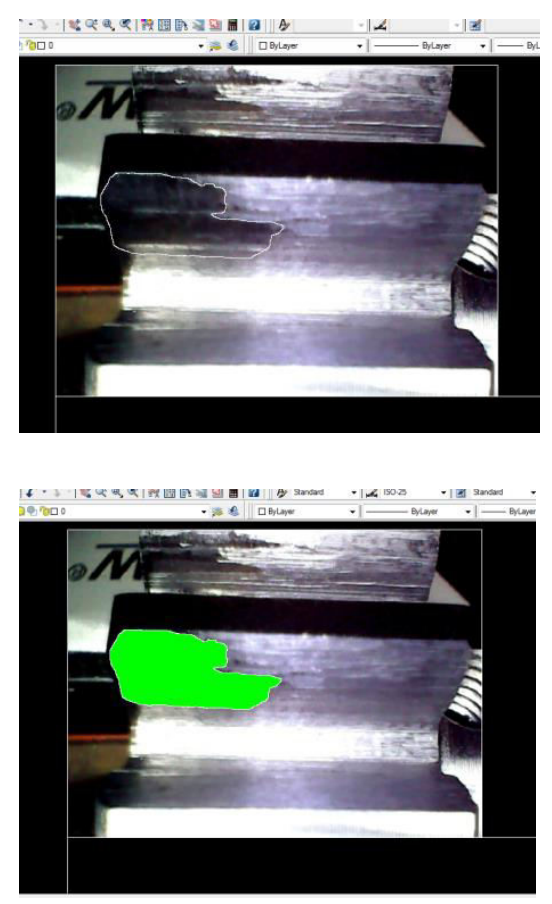

Figure 4. Sketch Result

\section{RESULT AND DISCUSSION}

\section{Results of Gear Wear Data 001}

In the 001 gear wear test, 200 rpm variable rotation without load with 150 minutes testing time. Data is taken every 30 minutes for each T1-T5 with the following data results:

Table 2. Average Wear on Gear 001

\begin{tabular}{|c|c|c|c|c|c|c|c|c|c|c|c|c|c|c|c|}
\hline \multirow{2}{*}{$\begin{array}{c}\text { No. Gigi } \\
1 \\
\end{array}$} & \multicolumn{3}{|c|}{ Area Keausan Gigi T1 } & \multicolumn{3}{|c|}{ Area Keausan Gigi T2 } & \multicolumn{3}{|c|}{ Area Keausan Gigi T3 } & \multicolumn{3}{|c|}{ Area Keausan Gigi T4 } & \multicolumn{3}{|c|}{ Area Keausan Gigi T5 } \\
\hline & 80,54 & 64,43 & 0,64 & 257,00 & 205,60 & 2,06 & 267,90 & 214,32 & 2,14 & 398,55 & 318,84 & 3,19 & 650,45 & 520,36 & 5,20 \\
\hline 2 & 154,19 & 123,35 & 1,23 & 293,06 & 234,45 & 2,34 & 319,27 & 255,42 & 2,55 & 458,58 & 366,86 & 3,67 & 492,80 & 394,24 & 3,94 \\
\hline 3 & 178,91 & 143,13 & 1,43 & 218,33 & 174,66 & 1,75 & 234,69 & 187,75 & 1,88 & 369,97 & 295,98 & 2,96 & 492,24 & 393,79 & 3,94 \\
\hline 4 & 44,32 & 35,46 & 0,35 & 131,71 & 105,37 & 1,05 & 258,51 & 206,81 & 2,07 & 275,64 & 220,51 & 2,21 & 298,00 & 238,40 & 2,38 \\
\hline 5 & 64,87 & 51,90 & 0,52 & 176,61 & 141,29 & 1,41 & 214,69 & 171,75 & 1,72 & 342,50 & 274,00 & 2,74 & 560,95 & 448,76 & 4,49 \\
\hline 6 & 108,41 & 86,73 & 0,87 & 229,82 & 183,86 & 1,84 & 307,30 & 245,84 & 2,46 & 327,58 & 262,06 & 2,62 & 502,56 & 402,05 & 4,02 \\
\hline 7 & 98,09 & 78,47 & 0,78 & 173,93 & 139,14 & 1,39 & 220,23 & 176,18 & 1,76 & 227,48 & 181,98 & 1,82 & 268,53 & 214,82 & 2,15 \\
\hline 8 & 83,12 & 66,50 & 0,66 & 242,15 & 193,72 & 1,94 & 320,81 & 256,65 & 2,57 & 396,29 & 317,03 & 3,17 & 502,96 & 402,37 & 4,02 \\
\hline 9 & 84,32 & 67,46 & 0,67 & 208,73 & 166,98 & 1,67 & 213,14 & 170,51 & 1,71 & 388,05 & 310,44 & 3,10 & 521,22 & 416,98 & 4,17 \\
\hline 10 & 115,85 & 92,68 & 0,93 & 201,16 & 160,93 & 1,61 & 278,61 & 222,89 & 2,23 & 349,52 & 279,62 & 2,80 & 611,92 & 489,54 & 4,90 \\
\hline 11 & 136,54 & 109,23 & 1,09 & 209,88 & 167,90 & 1,68 & 225,05 & 180,04 & 1,80 & 264,57 & 211,66 & 2,12 & 651,33 & 521,06 & 5,21 \\
\hline 12 & 55,20 & 44,16 & 0,44 & 146,34 & 117,07 & 1,17 & 243,09 & 194,47 & 1,94 & 271,63 & 217,30 & 2,17 & 523,33 & 418,66 & 4,19 \\
\hline 13 & 286,19 & 228,95 & 2,29 & 333,37 & 266,70 & 2,67 & 383,08 & 306,46 & 3,06 & 509,23 & 407,38 & 4,07 & 743,85 & 595,08 & 5,95 \\
\hline 14 & 90,54 & 72,43 & 0,72 & 189,46 & 151,57 & 1,52 & 328,99 & 263,19 & 2,63 & 407,45 & 325,96 & 3,26 & 631,08 & 504,86 & 5,05 \\
\hline 15 & 137,10 & 109,68 & 1,10 & 212,46 & 169,97 & 1,70 & 269,21 & 215,37 & 2,15 & 612,59 & 490,07 & 4,90 & 845,27 & 676,22 & 6,76 \\
\hline 16 & 65,23 & 52,18 & 0,52 & 136,86 & 109,49 & 1,09 & 241,04 & 192,83 & 1,93 & 542,93 & 434,34 & 4,34 & 848,67 & 678,94 & 6,79 \\
\hline 17 & 176,72 & 141,38 & 1,41 & 382,55 & 306,04 & 3,06 & 504,18 & 403,34 & 4,03 & 644,66 & 515,73 & 5,16 & 965,05 & 772,04 & 7,72 \\
\hline \multirow[t]{5}{*}{18} & 103,58 & 82,86 & 0,83 & 166,59 & 133,27 & 1,33 & 367,23 & 293,78 & 2,94 & 473,33 & 378,66 & 3,79 & 907,66 & 726,13 & 7,26 \\
\hline & & Rata-rata & 0,92 & & Rata-rats & 1,74 & & Rata-rata & 2,31 & & Rata-rata & 3,23 & & Rata-rata & 4,90 \\
\hline & & Maksimal & 2,29 & & Maksima & 3,06 & & Maksimal & 4,03 & & Maksimal & 5,16 & & Maksimal & 7,72 \\
\hline & & Minimal & 0,35 & & Minima & 1,05 & & Minimal & 1,71 & & Minimal & 1,82 & & Minimal & 2,15 \\
\hline & & Range & 1,93 & & Range & 2,01 & & Range & 2,33 & & Range & 3,34 & & Range & 5,57 \\
\hline
\end{tabular}


The results of the table above can be seen that at $200 \mathrm{rpm}$ rotation without load on T1 the average wear area is $0.92 \mathrm{~mm}$, the average area at T2 is $1.47 \mathrm{~mm}$, the average area of the T3 area is 2.31 $\mathrm{mm}$, At T4 it is $3.23 \mathrm{~mm}$, and the area at T5 is $4.90 \mathrm{~mm}$.

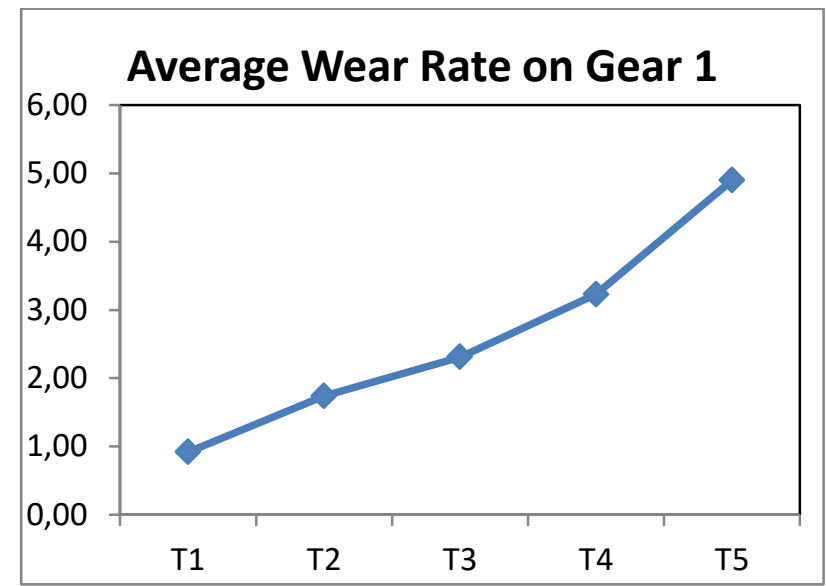

Figure 5. Average wear rate on gear 001.

\section{Discussion of Wear Speed Against Rotation Variations.}

The following is the result of the effect of rotation variations on the wear speed of gears 1-9.

Table 3. Table of Turns Variations and Load Variations

\begin{tabular}{|c|c|c|c|c|}
\hline & \multicolumn{3}{|c|}{ Variasi Beban (kg) } \\
\hline & & 0 & 5 & 10 \\
\hline \multirow{3}{*}{ 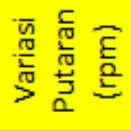 } & 200 & 0,032646 & 0,023512 & 0,023065 \\
\hline & 500 & 0,052337 & 0,035343 & 0,031548 \\
\hline & 1000 & 0,097929 & 0,038044 & 0,056506 \\
\hline
\end{tabular}

Based on the table of rotation variations and load variations above, it can be seen that at $200 \mathrm{rpm}$ a load of $0 \mathrm{~kg}$ is given a wear speed of $0.032646 \mathrm{~mm}^{2} / \mathrm{min}$. At $200 \mathrm{rpm}$ rotation given a load of $5 \mathrm{~kg}$ the wear speed has decreased to $0.023512 \mathrm{~mm}^{2} / \mathrm{min}$. At $200 \mathrm{rpm}$ a load of $10 \mathrm{~kg}$ is given, which results in a decrease in the wear speed of $0.023065 \mathrm{~mm}^{2} / \mathrm{min}$.
At $500 \mathrm{rpm}$ a load of $0 \mathrm{~kg}$ is given a wear speed of $0.052337 \mathrm{~mm}^{2} / \mathrm{min}$, at $500 \mathrm{rpm}$ a load of $5 \mathrm{~kg}$ is given, the wear speed decreases by $0.035343 \mathrm{~mm}^{2} / \mathrm{min}$, at $500 \mathrm{rpm}$ a load of $10 \mathrm{~kg}$ is given, which occurs the wear on the gears decreased to $0.031548 \mathrm{~mm}^{2} / \mathrm{min}$.

At $1000 \mathrm{rpm}$ a load of $0 \mathrm{~kg}$ is given, the wear speed is $0.097929 \mathrm{~mm}^{2} / \mathrm{min}$, at $1000 \mathrm{rpm}$ a load of $5 \mathrm{~kg}$ is given, which occurs when the wear speed of the gears decreases to $0.038044 \mathrm{~mm}^{2} / \mathrm{min}$, while at $1000 \mathrm{rpm}$ it is given a load of $10 \mathrm{~kg}$, which occurs the wear speed of the gears has increased to $0.056506 \mathrm{~mm}^{2} / \mathrm{min}$.

So that in this test the loading has a very significant effect on rotation so that when the load is given during the rotation, the wear on the gears will also decrease and this occurs in every wear test with varying loads.

This is due to the misalignment factor on the drive shaft and the driven one, this can be seen from the average wear position located at the end of the gear which is in direct contact between the drive gear and the driven gear, so that at high rotation and without loading the shaft rotation is not balanced, but at high speed and with certain loads the unbalance of rotation due to misalignment can be reduced and results in low wear values. From the results of the data in the table above, the graph is obtained, it can be seen in Figure 7. as follows: 


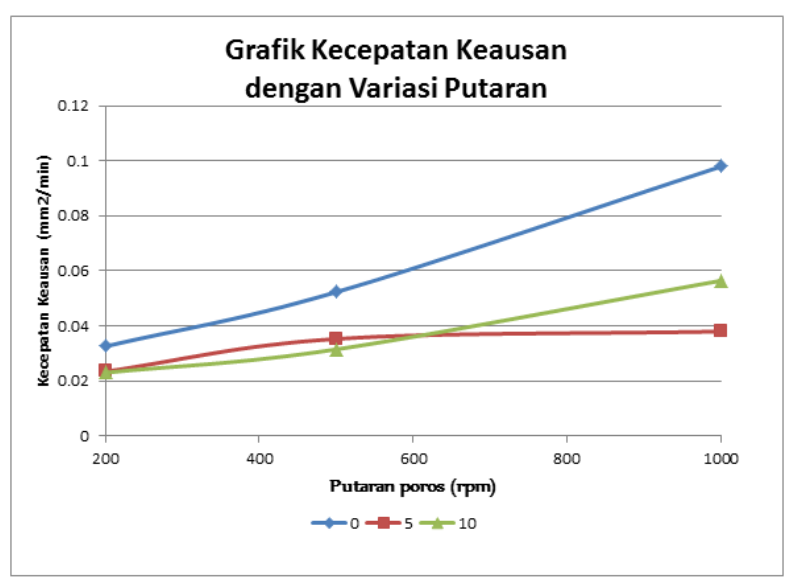

Figure 6. Wear speed graph with Rotation Variation

From the results of the graph above, this test, the loading is very influential on rotation, the faster the rotation is received on the gear, the lower the resulting load. The cause of the striking wear rate at 1000 rotation, because at $1000 \mathrm{rpm}$ rotation with a very high rotation, the wear rate will be unstable and the difference is very visible.

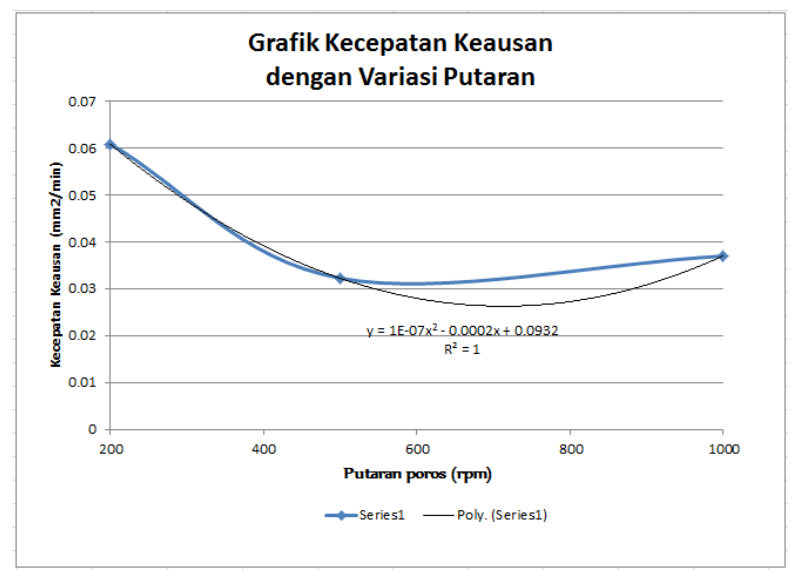

Figure 8. Wear Speed Graph with Variations in Rotation

Based on the graph above, it can be explained that the results of $\mathrm{R}^{2}=1$ if $\mathrm{R}^{2}$ approaches the value $=1$, then the results can be said to be accurate according to the wear theory. The heavier the load received on the gear, the greater the wear speed on the gear.

\section{CONCLUSION}

Based on the results of the straight untreatment gear wear test, the following conclusions are obtained:

1. The faster the rotation received on the gear, the lower the resulting load.

2. The behavior of the wear rate at $1000 \mathrm{rpm}$ rotation with a load of $5 \mathrm{~kg}$ has decreased linearly, namely a decrease that describes a straight line. Whereas at $500 \mathrm{rpm}$ and 1000 rpm with loads of 0,5 , and $10 \mathrm{~kg}$, they experienced a significant decrease and increase. The cause of the prominent wear rate is because at $1000 \mathrm{rpm}$ with a very high rotation, the wear rate will be very noticeable.

\section{REFERENCES}

[1] Gurupujaz. (2019, January 4). NamaNama Bagian Roda Gigi.

[2] Hastomo, R. (2018). Konstruksi dan Manufaktur Pengaruh Ketebalan Rim Terhadap Keausan Roda Gigi Lurus Komposit.

[3] Irawan, R. (2018). PENGARUH PEMBEBANAN TERHADAP KEKUATAN RODA GIGI LURUS KOMPOSIT. Konstruksi dan Manufaktur.

[4] Isranuri, Jamil, \& Suherman. (2011, January). PENGARUH PUTARAN TERHADAP LAJU KEAUSAN Al-Si ALLOY MENGGUNAKAN METODE PIN ON DISK TEST.

[5] Siregar, R., I Isranuri, \& Suherman. (2015). KAJIAN PERILAKU GETARAN TORSIONAL UNTUK DETEKSI KERUSAKAN RODA GIGI LURUS. Widya Teknika, 30-34. 
Febri Putra Perdana, Darto, I Made Sunada (2019), TRANSMISI, Vol-15, No. 2/ p. 414-420

[6] Sularso. (1991). Dasar Perencanaan dan Pemilihan Elemen Mesin. Jakarta: PT Pradya Paramita.

[7] Syahrani, A. (t.thn.). ANALISIS EKSPERIMENTAL CIRI KERUSAKAN RODA GIGI LURUS BERBASIS SPEKTRUM GETARAN. SMARTek.

[8] Widodo, A., \& D Satrijo. (2014). Deteksi Kerusakan Roda Gigi Dengan Analisis Sinyal Getaran Berbasis Domain Waktu. Jurnal Teknik Mesin . 